\title{
Characterization of long-term monolayer cultures of human granulosa cells from follicles of different size and exposed in vivo to clomiphene citrate and hCG
}

\author{
Cecilia L. Schmidt, June Z. Kendall*, Pramila V. Dandekar, \\ M. M. Quigley and Karmen L. Schmidt $\dagger$
}

University of Texas Medical School at Houston, Department of Obstetrics, Gynecology and Reproductive Sciences, and †Department of Pathology, 6431 Fannin Street, Houston, Texas 77030. U.S.A.

\begin{abstract}
Summary. To determine the effects of prolonged hCG treatment in vitro upon granulosa cells from follicles of various sizes previously exposed to clomiphene citrate and hCG in vivo, progesterone and relaxin concentrations of spent media were correlated with light microscopic and ultrastructural characteristics. Intact, freshly dispersed cells were characterized by numerous lipid droplets, elliptical mitochondria with tubular or lamellar cristae, moderate rough-surfaced endoplasmic reticulum (RER), sparse smooth-surfaced endoplasmic reticulum (SER), and few Golgi. After 10-24 days in culture, 2 morphologically distinct cell types, 'granulosa-type' and 'luteal-type', were noted at the light microscopic level. Ultrastructurally, lipid droplets decreased in number, mitochondria became pleomorphic, RER became more prominent and dilated, and Golgi became more widely dispersed. Tubular SER became abundant and annular nexuses became more numerous after hCG treatment in vitro. Granulosa cells generated from all follicles responded to hCG treatment with significantly increased progesterone secretion after 4 days in culture. Relaxin was not detectable in any sample of medium. This study shows that human granulosa cells from 15-25-mm follicles retain their differentiated function of progesterone secretion in long-term culture and recover responsiveness to hCG in vitro, as demonstrated by enhanced progesterone secretion and development of prominent SER and increased annular nexuses.
\end{abstract}

\section{Introduction}

In an attempt to study hormonal regulation of cellular function, human granulosa cells from follicular and luteal sources have been compared morphologically and hormonally. Electron microscopic studies of granulosa lutein cells in situ have revealed abundant tubular smoothsurfaced endoplasmic reticulum (SER), stacks of rough-surfaced endoplasmic reticulum (RER), large pleomorphic mitochondria, moderately extensive Golgi complexes, non-extractable lipid droplets and annular nexuses (Adams \& Hertig, 1969; Crisp, Dessouky \& Denys, 1970). Comparisons with follicular granulosa cells have recognized the transformation into granulosa lutein cells in vivo as the appearance of the prominent SER (Christensen \& Gillim, 1969). Granulosa cells isolated from healthy preovulatory follicles secrete progesterone in vitro for at least 6 days under basal conditions (McNatty, Makris, DeGrazia, Osathanondh \& Ryan, 1979; Batta, Wentz \&

* Present address: Department of Obstetrics and Gynecology and Department of Physiology and Biophysics, University of Texas Medical Branch, Galveston, Texas 77550, U.S.A. 
Channing, 1980). Progesterone secretion by luteal cells derived from the corpus luteum of the menstrual cycle has been stimulated by gonadotrophins in short-term (Williams, Roth, Marsh \& LeMaire, 1979; Richardson \& Masson, 1980) and long-term (Goldsmith, Essig, Sarosi, Beck \& Weiss, 1981) culture systems. However, in the study of Goldsmith et al. (1981), chorionic gonadotrophin did not stimulate relaxin secretion characteristic of the human luteal cell of pregnancy (O'Byrne et al., 1978).

Granulosa cells aspirated from follicles after exposure in vivo to the 'LH surge' present a transition phase between the follicular cell and the fully transformed luteal cell. In short-term studies in vitro, LH stimulated progesterone secretion by granulosa cells aspirated from follicles of diameter 5-19 mm from women in whom LH levels had previously risen above a surge level of 60 mi.u./ml. However, the same dose of $\mathrm{LH}$ had no effect on similarly treated granulosa cells from follicles $>20 \mathrm{~mm}$ in diameter over the same 24-h period (Bieszczad, McClintock, Pepe \& Domino, 1982). The purpose of our study was to characterize long-term cultures of granulosa cells from follicles of various sizes, previously exposed to clomiphene citrate and hCG in vivo, and to assess the effect of hCG treatment in vitro upon these granulosa cells. Our approach was to examine light microscopic and ultrastructural properties of these granulosa cells in vitro in conjunction with measurements of the concentrations of progesterone and relaxin in the media under basal conditions and after exposure to hCG.

\section{Materials and Methods}

Source of follicles. Three women participating in our in-vitro fertilization programme (Quigley, 1983) were treated with $50 \mathrm{mg}$ clomiphene citrate on cycle Days 5-9 inclusive (one patient underwent 2 treatment cycles). Follicular diameters were followed with daily ultrasonographic measurements beginning on Day 10. On the day that the largest follicle reached at least $20 \mathrm{~mm}$, each patient received an i.m. injection of 2500 i.u. hCG (Serono Laboratories, Randolph, MA, U.S.A.). After securing informed consent, granulosa cells were harvested from 15-25-mm follicles aspirated for oocyte retrieval via laparoscopy $36 \mathrm{~h}$ after hCG injection, approximately 2-4 h before ovulation would be expected to occur spontaneously (Edwards \& Steptoe, 1975). The method of oocyte retrieval entailed puncture of the preovulatory follicle, removal of follicular fluid and agitation of the follicle wall to free mural granulosa cells. To locate the oocyte, all 'cumulus-type' masses of granulosa cells were segregated. These masses of granulosa cells were cultured in vivo with the oocyte or were separated from the granulosa cells used in our experiments. Oocytes were incubated and fertilized as previously reported (Quigley, 1983). Embryos were transferred into the donor's uterus by transcervical catheter $48 \mathrm{~h}$ after insemination at the 2-4-cell stage. Pregnancy was detected by serum $\beta$-hCG radioimmunoassay and later confirmed by ultrasonographic examination in each of the 3 patients. Follicle and culture characteristics are detailed in Table 1.

Incubation of granulosa cells. Long-term monolayer cultures of human granulosa cells were established by modification of the method of Goldsmith et al. (1981). Throughout the 24 days of each experiment, granulosa cells remained separated according to the specific follicle of origin. Clumps and sheets of granulosa cells were removed from follicular fluid by centrifugation at $600 \mathrm{~g}$ for $10 \mathrm{~min}$ and incubated for $10 \mathrm{~min}$ in Earles Balanced Salt Solution without Ca or $\mathrm{Mg}$ (EBSS*) containing $0.2 \%$ collagenase and $0.01 \%$ deoxyribonuclease. The larger clumps of cells were dispersed by repeated pipetting through a Pasteur pipette for $5 \mathrm{~min}$. The cell suspension was centrifuged at $600 \mathrm{~g}$ for $10 \mathrm{~min}$ and the pellet was resuspended in Medium EBSS*. Granulosa cells were counted with a haemocytometer and plated on a glass cover-slip in a $35-\mathrm{mm}$ plastic Petri dish (Falcon, Division of Becton, Dickinson and Co., Cockeysville, MD, U.S.A.) at a concentration of $1.0 \times 10^{5}$ viable cells. These glass cover-slips had been sequentially washed with $50 \% \mathrm{HNO}_{3}$, water, $1 \%$ NaEDTA, distilled-deionized water and $70 \%$ ethanol. The number of granulosa cells recovered from each follicle ranged from $2.0 \times 10^{5}$ to $50.0 \times 10^{5}$, with a mean \pm s.e.m. of $16.6 \times$ $10^{5} \pm 14.6 \times 10^{5}$ 
The granulosa cells were maintained in vitro for up to 24 days in Medium 199, supplemented with $10 \%$ fetal calf serum, 100 units penicillin $/ \mathrm{ml}, 100 \mu \mathrm{g}$ streptomycin $/ \mathrm{ml}$ and $2 \mathrm{~mm}$-L-glutamine (Grand Island Biological Company, Grand Island, New York, U.S.A.). From each of 9 follicles, 16 plates remained untreated and 1-6 plates were exposed to $100 \mathrm{i} . \mathrm{u}$. hCG/ml (NICHD, Bethesda, MD: Batch CR-121) throughout the experiment. Culture media were changed every 2 days and spent media were stored at $-20^{\circ} \mathrm{C}$ until assayed for progesterone and relaxin by RIA. Morphological changes were assessed at 2 -day intervals by phase-contrast microscopy. Viability was monitored by trypan blue exclusion at the start and end of each experiment. After 24 days in culture, a dissecting microscope $(\times 80)$ was used to estimate the relative proportion of 'granulosa type' and 'luteal type' cells on each plate, as described in 'Results'. Cells not fixed for en bloc electron microscopy were then moved from plates using 0.25\% trypsin (Sigma Chemical Co., St Louis, MO, U.S.A.: 230 units $/ \mathrm{mg}$ ) in Medium EBSS* and counted with a haemocytometer.

Electron microscopy. Electron microscopic studies were performed on Follicles $2 \mathrm{~L}_{1}$ (dispersed cells, Days 2, 10 and 24), 2R (dispersed cells, Days 2 and 24) and $3 \mathrm{~L}_{1}$ (dispersed cells, Days 10 and 24). Samples of dispersed cells were centrifuged at $600 \mathrm{~g}$ for $10 \mathrm{~min}$ and immediately fixed in $2.5 \%$ glutaraldehyde in $0.1 \mathrm{M}$-sodium cacodylate buffer, $\mathrm{pH} 7 \cdot 4$. Cell samples obtained after 2,10 or 24 days of culture were fixed on the plates or removed from the plates with $0.25 \%$ trypsin in Medium EBSS*, incubated at $37^{\circ} \mathrm{C}$ for $15 \mathrm{~min}$ and centrifuged at $600 \mathrm{~g}$ for $10 \mathrm{~min}$. After washing with Medium EBSS*, the pellets were fixed as above. All samples were rinsed in $0.1 \mathrm{M}$-sodium cacodylate buffer, osmicated in $1 \%$ osmium tetroxide in cacodylate buffer, dehydrated in a graded series of ethanol and embedded in Spurr resin (Electron Microscopy Sciences, Ft Washington, PA). Gold-to-silver sections were stained with uranyl acetate and lead citrate and examined in a JEOL $100 \mathrm{~B}$ electron microscope.

Radioimmunoassays. Concentrations of progesterone were determined by radioimmunoassay (Kendall, Richards \& Shih, 1983). Duplicate $25 \mu \mathrm{l}$ samples of media from cultured cells were extracted once with $3 \mathrm{ml}$ petroleum ether (b. pt $42-60^{\circ} \mathrm{C}$ ) with an average efficiency of $82 \%$. The ether extracts were dried under nitrogen and redissolved in phosphate buffer (400 $\mu \mathrm{l}$ to $2 \mathrm{ml})$. Aliquants were taken for RIA. The sensitivity of the RIA was $6 \mathrm{pg}$. Serial dilutions of medium samples gave progesterone values with a mean coefficient of variation of $4.9 \%$. Recoveries of $75 \mathrm{pg}$ and $150 \mathrm{pg}$ progesterone added to progesterone-free culture medium were $89 \%$ and $92 \%$, respectively. The interassay coefficients of variation for these standard samples were $24 \%$ (mean \pm s.d. $=80 \cdot 2 \pm 19 \cdot 0 \mathrm{pg}, n=37)$ and $16 \%(178 \cdot 0 \pm 28.5 \mathrm{pg}, n=48)$. The interassay coefficients of variation were $15 \%(3.23 \pm 0.50 \mathrm{ng} / \mathrm{ml}, n=21)$ for plasma samples from men and $12 \%(63.70 \pm$ $7.50 \mathrm{ng} / \mathrm{ml}, n=40$ ) for plasma from pregnant women.

Relaxin was measured by an homologous porcine radioimmunoassay (Kendall, Richards, Shih \& Farris, 1982; Kendall et al., 1983) incorporating modifications needed to determine concentrations of the hormone in media from cells in culture. Six NIH-RXN-PI standards ranging from 62.5 to $200 \mathrm{pg} / 100 \mu \mathrm{l}$ buffer were incubated with $400 \mu \mathrm{l}$ culture medium, $100 \mu$ l R6 antiporcine relaxin serum (final dilution $1: 50000$ ) and $100 \mu \mathrm{l}^{125} \mathrm{I}$-labelled porcine relaxin at $4^{\circ} \mathrm{C}$ for $48 \mathrm{~h}$. The sensitivity of the RIA was $100 \mathrm{pg}$. The assay of 122,163 and $816 \mathrm{pg}$ of relaxin added to relaxin-free culture medium gave values of $99 \%, 102 \%$ and $72 \%$, respectively. Culture medium blanks gave nondetectable values. The detection of relaxin in human menstrual corpora lutea has previously been documented (O'Byrne et al., 1978).

All culture medium samples from a given experiment were assayed in the same progesterone and relaxin RIAs to avoid interassay variability. All RIA values were calculated by a W.H.O. programme developed by Malan \& Edwards (1981).

Statistics. Progesterone concentrations in media were analysed by multiple and stepwise linear regressions using BMDP programs $1 R$ and 2R (BMDP Statistical Software, 1983), respectively. Independent variables were patient cycles, follicular size, day of culture and hCG treatment. Significance was defined as $P<0.05$. 


\section{Results}

\section{Culture characteristics}

The granulosa cells survived well in monolayer culture for up to 24 days. Viability was not affected by hCG (100 i.u./ml), remaining between 80 and $90 \%$ throughout each experiment. When examined with inverted phase microscopy after 2 days in culture, the granulosa cells appeared stellate with prominent nuclei and intracytoplasmic granules. Cytoplasmic processes seemed to bridge these 'fibroblast-like' cells (Pl. 1, Fig. 1). By 6 days in culture, this 'luteal-type' cell with fibroblast-like morphology was accompanied by a second cell type with a smooth round-to-ovoid shape and a higher nucleus-to-cytoplasm ratio (PI. 1, Fig. 2). Two morphologically distinct populations were apparent after 10 days in culture: (1) elongated 'luteal-type' cells (Pl. 2, Fig. 3) with granular cytoplasm in close juxtaposition and (2) round-to-polygonal 'granulosa-type' cells with increased nucleus-to-cytoplasm ratio (Pl. 2, Fig. 4). These latter occurred in rosette-like formations resembling Call-Exner bodies (Blaustein, 1977). The area between these cells was spanned by very fine cellular processes (Pl. 3, Fig. 5). Although a few areas of the plates exhibited a predominance of a single cell type, the 'luteal-type' and 'granulosa-type' cells were most often intermingled (Pl. 3, Fig. 6). The plating characteristics established by Day 10 of culture continued throughout the remainder of the experiments. Both types of cells remained in monolayer with only a few areas of cells piling upon one another. The major portion of most plates was occupied by the 'luteal-type' cells as indicated in Table 1.

Table 1. Characteristics of follicular sources of granulosa cells and culture profiles after 24 days

\begin{tabular}{|c|c|c|c|c|c|c|c|c|c|}
\hline \multicolumn{6}{|c|}{$\begin{array}{l}\text { Clinical evaluation of follicles } \\
\text { aspirated for granulosa cells }\end{array}$} & \multicolumn{4}{|c|}{$\begin{array}{c}\text { In-vitro characteristics of granulosa cells } \\
\text { after } 24 \text { days }\end{array}$} \\
\hline \multirow{2}{*}{\multicolumn{2}{|c|}{$\begin{array}{c}\text { Follicle } \\
\text { designation }\end{array}$}} & \multirow{4}{*}{$\begin{array}{c}\text { Follicle } \\
\text { diam. } \\
(\mathrm{mm})\end{array}$} & \multicolumn{3}{|c|}{ Outcome } & \multirow{3}{*}{\multicolumn{2}{|c|}{$\begin{array}{l}\text { Average approximate } \\
\% \text { of plates covered by } \\
\text { 'granulosa-type' cells } \\
\text { (number of plates) }\end{array}$}} & \multirow{3}{*}{\multicolumn{2}{|c|}{$\begin{array}{c}\text { No. of cells after } \\
24 \text { days/no. } \\
\text { at start } \\
\text { of culture }( \pm \text { s.e.m. })\end{array}$}} \\
\hline & & & \multirow{3}{*}{$\begin{array}{l}\text { Oocyte } \\
\text { retrieved }\end{array}$} & \multirow{3}{*}{$\begin{array}{c}\text { Oocyte } \\
\text { fertilized } \\
\text { and embryo } \\
\text { transferred }\end{array}$} & \multirow{3}{*}{$\begin{array}{l}\text { Pregnancy } \\
\text { achieved }\end{array}$} & & & & \\
\hline \multirow{2}{*}{$\begin{array}{l}\text { Patient } \\
\text { cycle }\end{array}$} & \multirow{2}{*}{$\begin{array}{l}\text { Ovarian } \\
\text { follicle }\end{array}$} & & & & & & & & \\
\hline & & & & & & Control & 100 i.u. hCG/ml & Control & 100 i.u. hCG $/ \mathrm{ml}$ \\
\hline 1 & $\mathrm{~L}_{1}$ & 25 & Yes & Yes & Yes & $40(4)$ & $30(4)$ & $6.0( \pm 0.3)$ & $4.3( \pm 0.1)$ \\
\hline 1 & $\mathbf{R}_{1}$ & 15 & No & - & - & $90(1)$ & $100(1)$ & $7 \cdot 1(-)$ & $6.9(二)$ \\
\hline $2^{*}$ & $\mathrm{~L}_{1}$ & 23 & No & - & - & $10(4)$ & $5(4)$ & $3.8( \pm 0.2)$ & $4 \cdot 1( \pm 0 \cdot 3)$ \\
\hline 2 & $\mathrm{R}_{1}$ & 22 & Yes & Yes & No & $5(3)$ & $10(3)$ & $2 \cdot 5( \pm 0 \cdot 1)$ & $3.5( \pm 0.5)$ \\
\hline 3 & $\mathrm{~L}_{1}$ & 18 & Yes & Yes & & $5(4)$ & $5(4)$ & $1.9( \pm 0.3)$ & $2 \cdot 1( \pm 0.3)$ \\
\hline 3 & $\mathbf{R}_{1}$ & 22 & Yes & Yes & Yes & $50(4)$ & $60(4)$ & - & - \\
\hline $4^{*}$ & $\mathrm{~L}_{1}$ & 15 & Yes & Yes & & $90(1)$ & $80(2)$ & $5.9(--)$ & $3.6( \pm 1 \cdot 2)$ \\
\hline 4 & $\mathrm{~L}_{2}$ & 15 & Yes & No & $($ Yes $) \dagger$ & $5(1)$ & $5(1)$ & $1.8(-)$ & $4 \cdot 4(-)$ \\
\hline 4 & $\mathrm{R}_{1}$ & 18 & Yes & Yes & & $20(6)$ & $30(6)$ & $3.8( \pm 0.5)$ & $3.0( \pm 0.4)$ \\
\hline
\end{tabular}

* These were two successive treatment cycles in the same patient.

$\dagger \mathrm{A}$ fourth follicle, $20 \mathrm{~mm}$ in diameter, was also aspirated during this patient cycle and resulted in a fertilized oocyte and embryo transfer. Granulosa cells from this follicle were not cultured.

After 24 days, 'granulosa-type' cells covered approximately $90 \%$ of the plates generated from two $15-\mathrm{mm}$ follicles $\left(1 \mathrm{R}_{1}\right.$ and $\left.4 \mathrm{~L}_{1}\right)$ but only $5 \%$ of a third $15-\mathrm{mm}$ follicle $\left(4 \mathrm{~L}_{2}\right)$ as noted in Table 1 . In contrast, the 18-25-mm follicles produced plates in which the 'granulosa-type' cells constituted only $5-60 \%$ of the cell population. The estimation of plating distribution between 'granulosa-type' and 'luteal-type' cells did not warrant statistical comparison. However, there appeared to be a tendency for a predominance of 'granulosa-type' cells to plate from the smaller follicles.

Under basal conditions and after hCG treatment, the number of cells removed from the plates after 24 days surpassed the number plated (Table 1). An aliquant of buffer calculated to contain 1.0 


\section{PLATE 1}
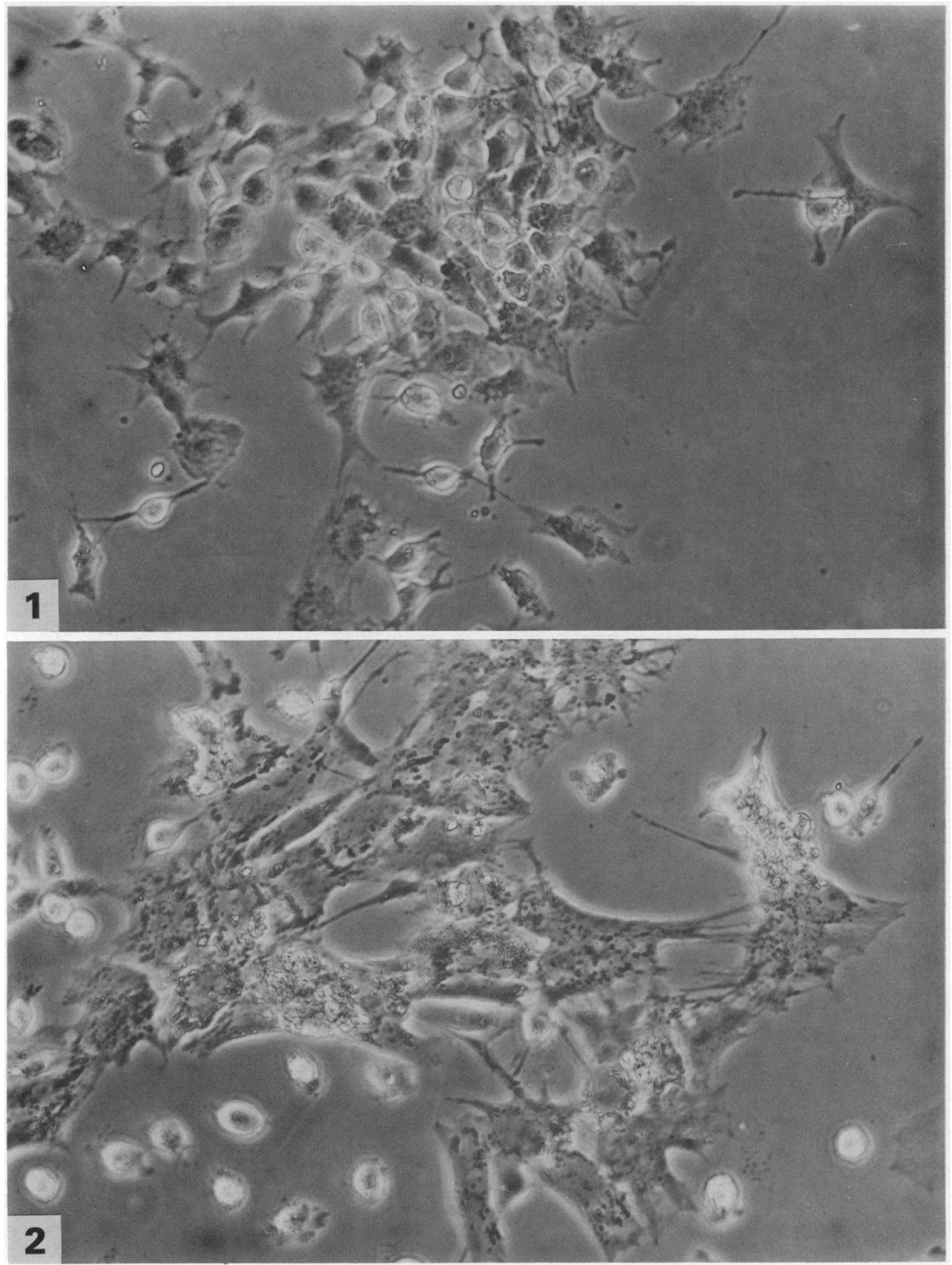

Light photomicrographs of human granulosa cells harvested from follicles exposed in tito to clomiphene citrate and hCG.

Fig. 1. After 2 days in culture. 'Fibroblast-like' cells are seen. $\times 950$.

Fig. 2. After 6 days in culture. 'Fibroblast-like' cells and smooth-surfaced round-to-ovoid cells, with a higher nucleus-to-cytoplasm ratio, are adherent to the plates. $\times 950$. 
PLATE 2
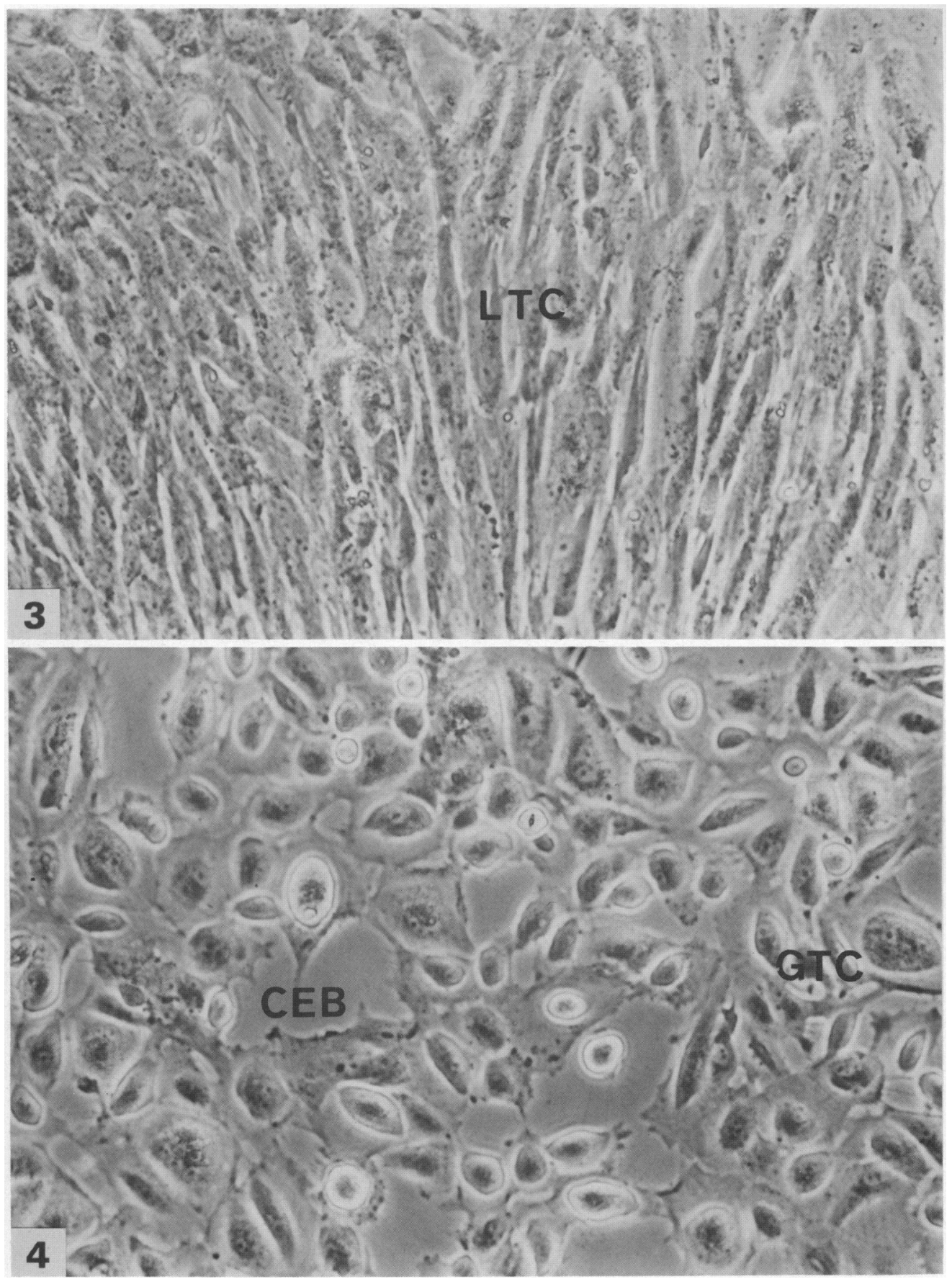

Light photomicrographs of the appearances of the 2 types of cells after 10 days in culture.

Fig. 3. 'Luteal-type' cells (LTC) comprising a lawn of closely apposed elongated cells. $\times 950$.

Fig. 4. 'Granulosa-type' cells (GTC) with rounded-to-polygonal contours, occurring in rosettelike formations resembling Call-Exner bodies (CEB). $\times 950$. 
PLATE 3
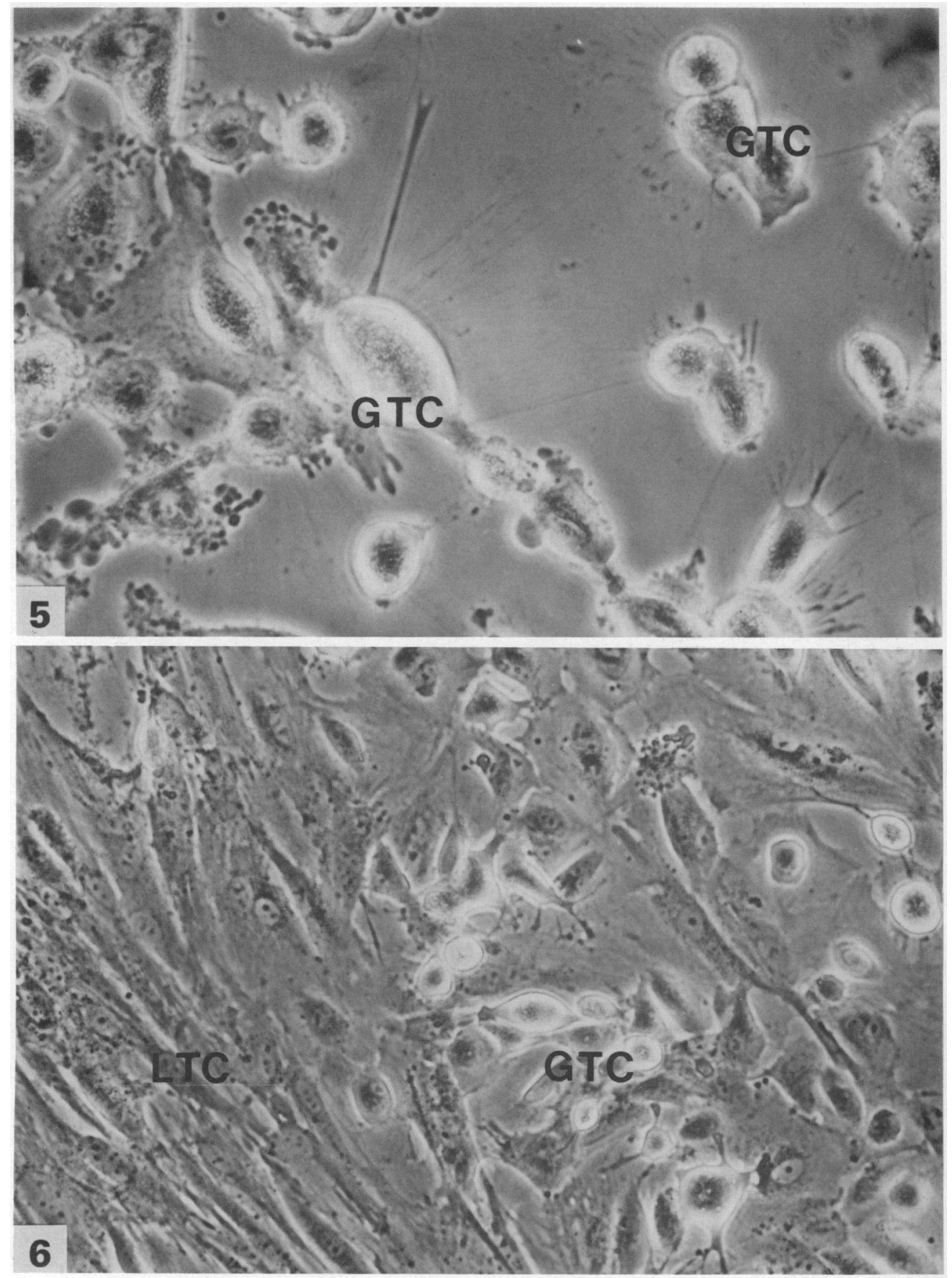

Fig. 5. Very fine processes extending between 'granulosa-type' cells (GTC). × 1900 .

Fig. 6. 'Luteal-type' cells (LTC) and 'granulosa-type' cells (GTC), in close proximity. $\times 950$. 
PLATE 4
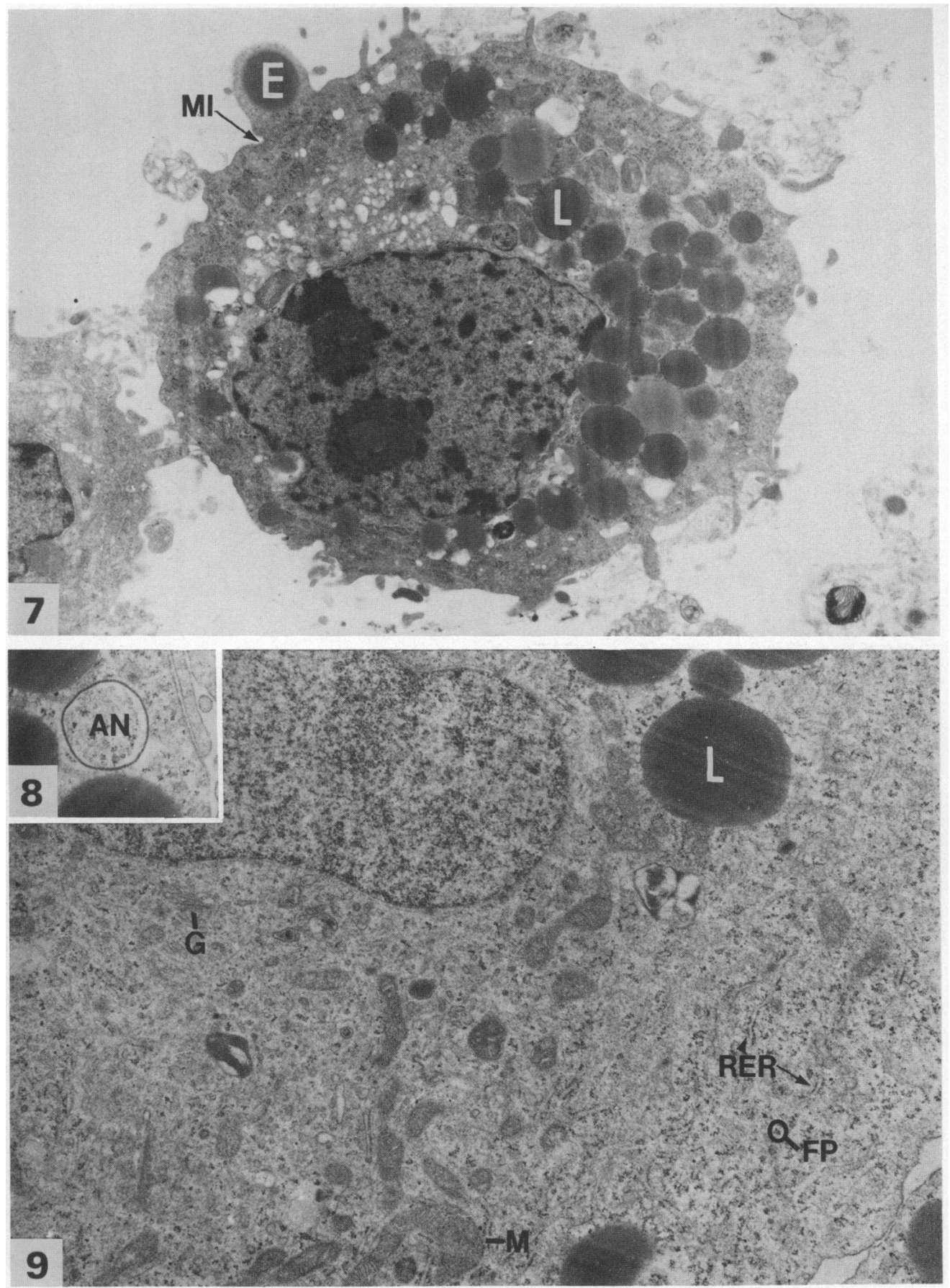

Transmission electron micrographs of freshly isolated granulosa cells from follicles previously exposed in tivo to clomiphene citrate and hCG.

Fig. 7. A dispersed cell. The predominant feature is non-extractable lipid droplets (L). Points of exocytosis of lipid droplets (E) are coupled with membranous infoldings (MI). $\times 12000$.

Fig. 8. Annular nexuses (AN) noted in these granulosa cells after dispersion. $\times 20000$.

Fig. 9. Perinuclear cytoplasm. Smooth-surfaced endoplasmic reticulum is scarce in these cells while rough-surfaced endoplasmic reticulum (RER) is found amidst free polyribosomes (FP). Note perinuclear Golgi $(\mathrm{G})$ and bacilliform mitochondria $(\mathrm{M}) . \times 22000$. 

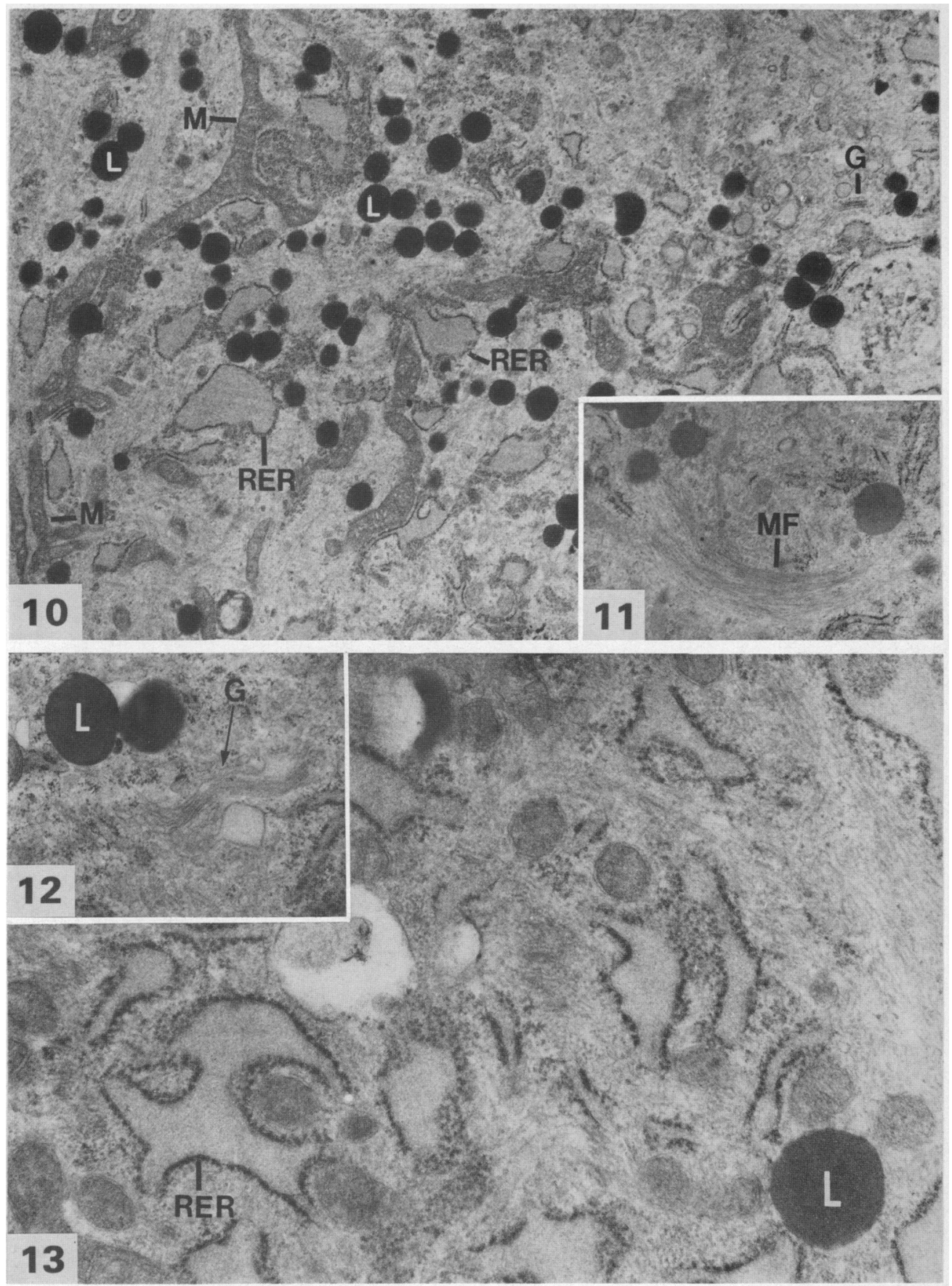

Transmission electron micrographs of untreated cells after 10 days of culture.

Fig. 10. Non-extractable lipid droplets (L) are relatively unchanged. The rough-surfaced endoplasmic reticulum (RER) has become more prominent and dilated, but smooth-surfaced endoplasmic reticulum remains scarce. Mitochondria $(\mathbf{M})$ have become more pleomorphic with branching. Golgi $(G)$ is now dispersed throughout the cytoplasm. $\times 14000$.

Fig. 11. Microfilaments (MF) have become more noticeable. $\times 18000$.

Fig. 12. Golgi apparatus $(\mathrm{G})$ is easily identified. $\times 31000$.

Fig. 13. Prominent dilated RER is noted after 10 days of culture. $\times 52000$. 
PLATE 6

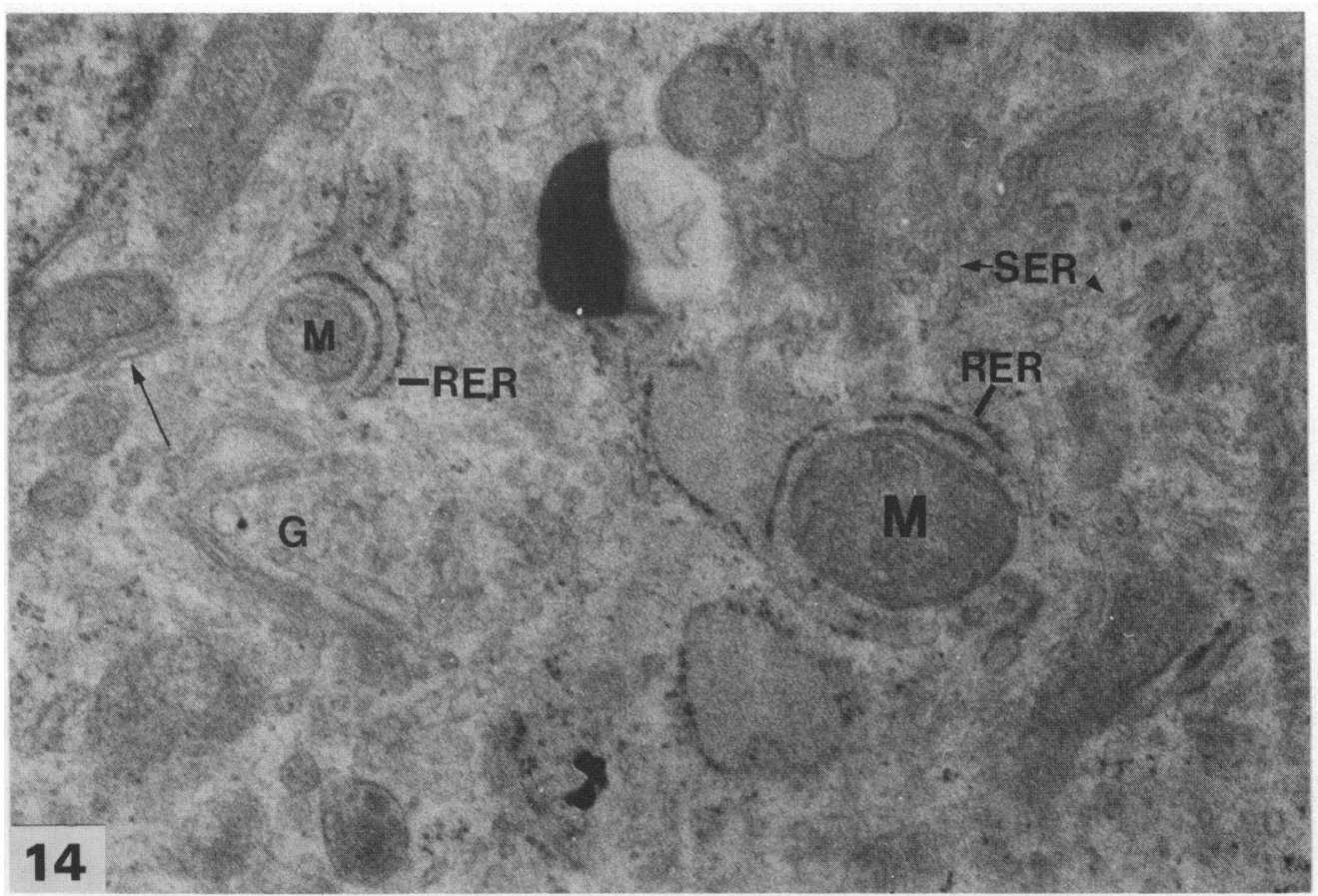

Fig. 14. Transmission electron micrograph of a cell exposed to hCG in vitro for 10 days. The main difference between this treated cell and those depicted in Plate 5 (10 days untreated) is the increase in the amount of smooth-surfaced endoplasmic reticulum (SER). Note rough-surfaced endoplasmic reticulum (RER) enveloping mitochondria (M), characteristic of active protein synthesis and branching of SER from RER (arrow). $\times 54000$. 


\section{PLATE 7}
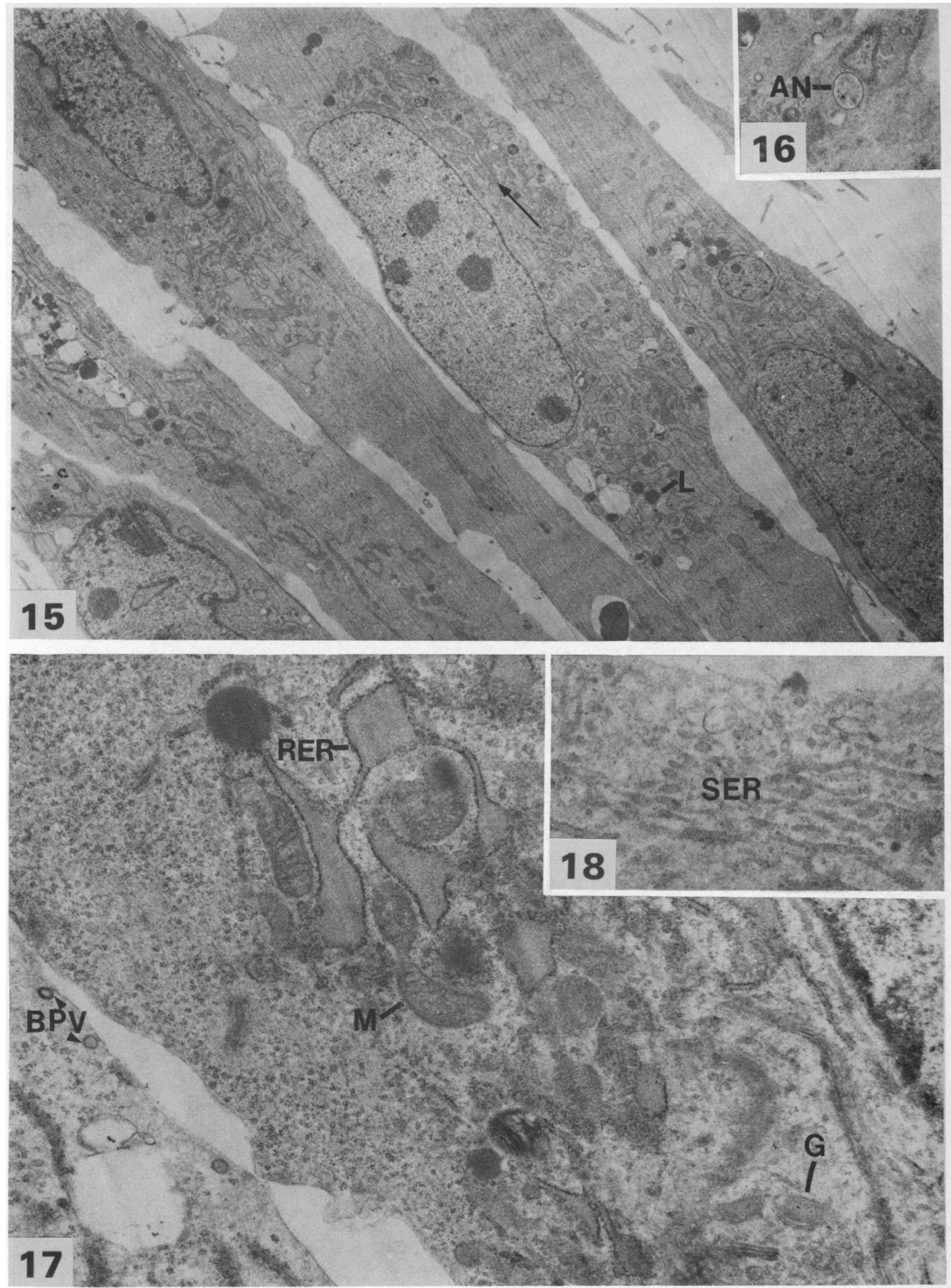

Transmission electron micrographs after 24 days in culture under basal conditions.

Fig. 15. Low-power view. Non-extractable lipid droplets (L) have decreased in number compared to those in treated and untreated earlier cultures. The relative proportions of endoplasmic reticulum and the bizarre branching mitochondria (arrow) closely resemble those of Day- 10 cells not exposed to hCG in vitro. $\times 5000$.

Fig. 16. Annular nexus (AN) resembling those of Day 10 cells untreated. $\times 12000$.

Fig. 17. High-power view. The bristled pinocytotic vesicles (BPV), the dilated rough-surfaced endoplasmic reticulum (RER) and the bizarre mitochondria (M) are similar to those of Day-10 cells not exposed to hCG. $\times 26000$.

Fig. 18. Sparse smooth-surfaced endoplasmic qreticulum $\mathrm{f}(\mathrm{SER}) \mathrm{ssc}$ attereda within the 6 cells, 12:32:10AM $\times 24000$. 
PLATE 8
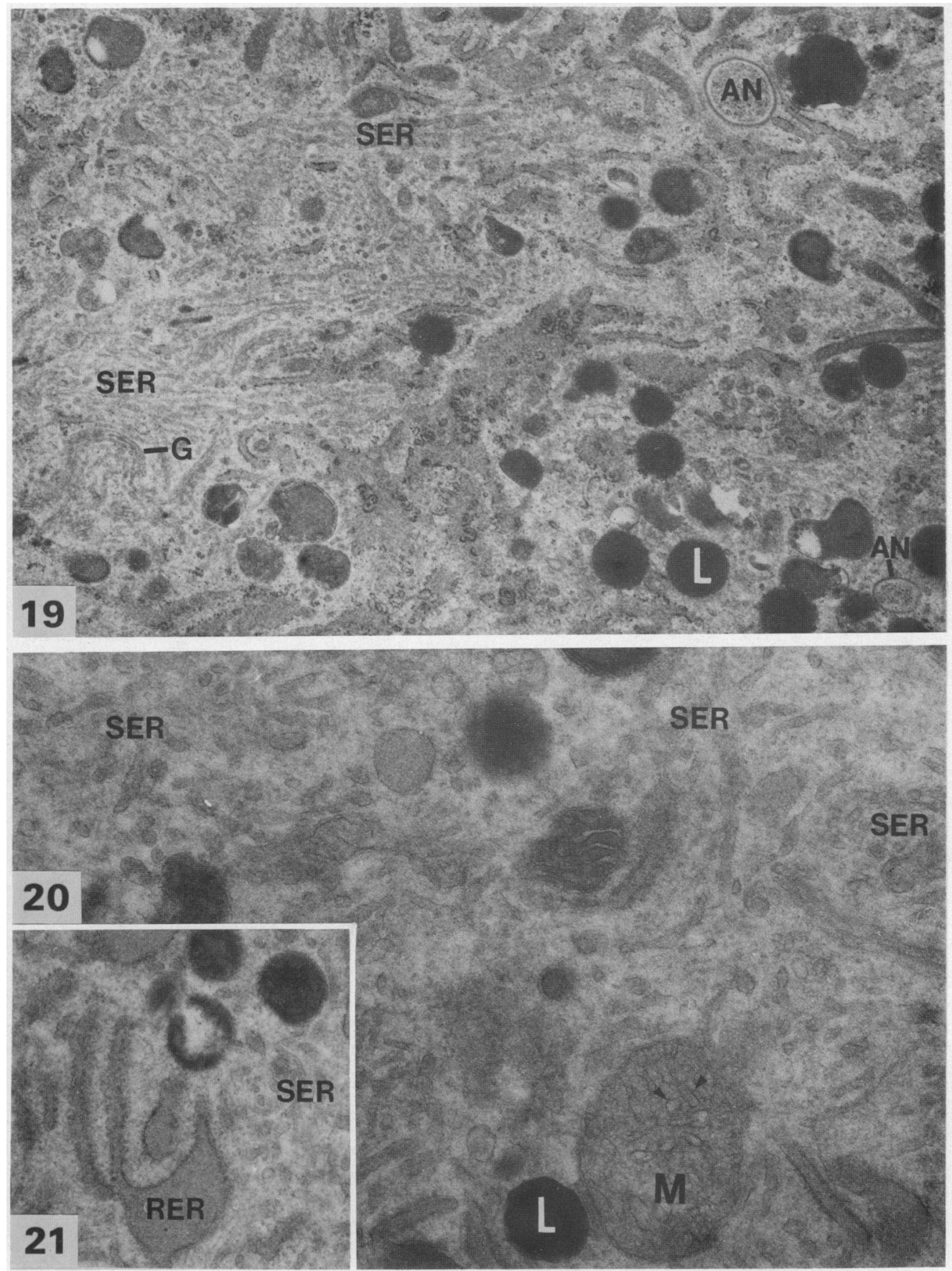

Transmission electron micrographs of granulosa cells exposed to hCG in vitro for 24 days.

Fig. 19. The 2 striking changes between these cells and those not exposed to hCG in vitro are the enhancement of abundant smooth-surfaced endoplasmic reticulum (SER) and the increase in the number of annular nexuses (AN). $\times 19000$.

Fig. 20. Note tubular cristae (arrow) within mitochondria (M). $\times 53000$.

Fig. 21. SER is seen in close juxtaposition to rough-surfaced endoplasmic reticulum (RER). $\times 34000$. 
$\times 10^{5}$ viable cells had been originally distributed to each culture dish, but $1.8 \times 10^{5}$ to $7 \cdot 1 \times 10^{5}$ viable cells were retrieved by trypsinization at 24 days. There was no significant difference between control plates (mean \pm s.e.m. $=4.1 \times 10^{5} \pm 0.4 \times 10^{5}$ cells/plate) and hCG-stimulated cultures $\left(3.7 \times 10^{5} \pm 0.3 \times 10^{5}\right.$ cells/plate $)$.

\section{Fine structure of isolated and cultured cells}

The predominant feature of freshly isolated granulosa cells from these follicles was nonextractable lipid droplets (Pl. 4, Figs 7, 8 \& 9). The cells exhibited multiple infoldings of the cell surface and exocytosis of lipid droplets. SER was limited, but RER and free polyribosomes were scattered throughout the cells. Golgi were limited to perinuclear locations. Elliptical and bacilliform mitochondria exhibited tubular and lamellar cristae. Annular nexuses were present. After 2 days in culture, little ultrastructural modification had occurred. By 10 days in culture (Pl. 5, Figs. 10,11,12\& 13), the relative proportion of non-extractable lipid droplets remained the same. However, RER had become more prominent and dilated and Golgi had become more widely dispersed. Pleomorphism and branching now characterized the mitochondria. Microfilaments were abundant. hCG effected an increase in the amount of SER as evident in Pl. 6, Fig. 14.

As shown in Pl. 7 (Figs 15, 16, 17 \& 18) and Pl. 8 (Figs 19, 20 \& 21), Day-24 cells under basal conditions and those of hCG exposure differed from earlier cultures by a decrease in nonextractable lipid droplets and more prominent microfilaments. The trend of enhancement of SER by gonadotrophin continued at 24 days of culture. Furthermore, the number of annular nexuses increased with hCG exposure.

\section{Hormonal studies}

Progesterone was detected in the media of all plates containing granulosa cells throughout the 24-day culture period. Under basal conditions, progesterone levels declined over the first 10 days and gradually plateaued. In accord with observations previously noted for luteal cells by other authors (Dennefors, Sjogren \& Hamberger, 1982b), we found a wide variation in basal levels of progesterone which was not related to follicular diameter (Table 2). For instance, on Day 2 the

Table 2. Progesterone levels $(\mathrm{ng} / \mathrm{ml})$ in media, reflecting secretion over the 2 days of culture before collection

\begin{tabular}{|c|c|c|c|c|c|c|c|c|}
\hline \multirow[b]{3}{*}{ Follicle } & \multicolumn{8}{|c|}{ Day of culture } \\
\hline & \multicolumn{2}{|r|}{ Day 2} & \multicolumn{2}{|r|}{ Day 4} & \multicolumn{2}{|c|}{ Day 10} & \multicolumn{2}{|r|}{ Day 24} \\
\hline & Control & 100 i.u. hCG $/ \mathrm{ml}$ & Control & 100 i.u. hCG $/ \mathrm{ml}$ & Control & 100 i.u. hCG $/ \mathrm{ml}$ & Control & 100 i.u. hCG $/ \mathrm{ml}$ \\
\hline $1 L_{1}$ & $\begin{array}{r}2324 \\
\pm 481 \cdot 0\end{array}$ & $\begin{array}{r}1625 \\
+139.0\end{array}$ & $\begin{array}{r}2238 \\
+\quad 387.0\end{array}$ & $\begin{array}{r}3430 \\
+420.0\end{array}$ & $\begin{array}{r}128 \\
+15.8\end{array}$ & $\begin{array}{r}723 \\
\pm 199.0\end{array}$ & $\begin{array}{r}200 \\
\pm 33.3\end{array}$ & $\begin{array}{r}329 \\
\pm \quad 32.5\end{array}$ \\
\hline $\mathbf{I R}_{\mathbf{I}}$ & 5041 & 4268 & 1674 & 3752 & 64 & 110 & 28 & 32 \\
\hline $2 \mathrm{~L}_{1}$ & $\begin{array}{r}455 \\
+143.4\end{array}$ & $\begin{array}{r}489 \\
+39.7\end{array}$ & $\begin{array}{r}541 \\
+115.8\end{array}$ & $\begin{array}{r}1107 \\
\pm 178.1\end{array}$ & $\begin{array}{r}28 \\
+4.0\end{array}$ & $\begin{array}{r}516 \\
\pm 48.4\end{array}$ & $\begin{array}{r}20 \\
+36\end{array}$ & $\begin{array}{r}33 \\
\pm 4.6\end{array}$ \\
\hline $2 \mathbf{R}_{1}$ & $\begin{array}{r}325 \\
+113.1\end{array}$ & $\begin{array}{r}419 \\
+72.4\end{array}$ & $\begin{array}{r}548 \\
\pm 130.2\end{array}$ & $\begin{array}{r}635 \\
+65.9\end{array}$ & $\begin{array}{r}76 \\
+15.5\end{array}$ & $\begin{array}{r}468 \\
+19.0\end{array}$ & $\begin{array}{r}5 \\
\pm 1.7\end{array}$ & $\begin{array}{r}10 \\
+1.4\end{array}$ \\
\hline $3 \mathbf{L}_{1}$ & $\begin{array}{r}3.1 \\
+0.4\end{array}$ & $\begin{array}{r}4.3 \\
\pm 0.6\end{array}$ & $\begin{array}{r}4.3 \\
\pm 0.7\end{array}$ & $\begin{array}{r}3.8 \\
+1.5\end{array}$ & $\begin{array}{r}2.8 \\
+0.4\end{array}$ & $\begin{array}{r}5.3 \\
\pm 0.9\end{array}$ & $\begin{array}{r}11.7 \\
\pm 1.1\end{array}$ & $\begin{array}{r}19.9 \\
+3.6\end{array}$ \\
\hline $3 \mathbf{R}_{1}$ & $4 \cdot 0$ & 3.6 & 1.8 & $4 \cdot 7$ & $3 \cdot 2$ & $3 \cdot 4$ & - & - \\
\hline $4 L_{1}$ & $\begin{array}{r}230 \\
+31.5\end{array}$ & $\begin{array}{r}465 \\
+150.5\end{array}$ & $\begin{array}{r}671 \\
\pm 175 \cdot 0\end{array}$ & $\begin{array}{r}1020 \\
+146.0\end{array}$ & $\begin{array}{r}177 \\
+79.0\end{array}$ & $\begin{array}{r}182 \\
+27.5\end{array}$ & $\begin{array}{r}8 \\
-\quad\end{array}$ & $\begin{array}{r}40 \\
\pm 4.4\end{array}$ \\
\hline $4 L_{2}$ & 108 & 241 & 176 & 368 & 59 & 348 & 103 & 168 \\
\hline $4 R_{1}$ & $\begin{array}{r}1543 \\
\pm 162.1\end{array}$ & $\begin{array}{r}2029 \\
\pm \quad 349.9\end{array}$ & $\begin{array}{r}1825 \\
+201 \cdot 0\end{array}$ & $\begin{array}{r}2121 \\
\pm 272 \cdot 3\end{array}$ & $\begin{array}{r}584 \\
+63.6\end{array}$ & $\begin{array}{r}1465 \\
\pm 107.7\end{array}$ & $\begin{array}{r}340 \\
\pm 40.0\end{array}$ & $\begin{array}{r}840 \\
\pm 134 \cdot 3\end{array}$ \\
\hline
\end{tabular}

Values are mean \pm s.e.m. The number of culture plates generated from each follicle corresponds to the value given in Table 1 with the exception of Follicle $4 L_{1}$ control plates (Days 2, 4 and 10:2 plates each; Day 24: 1 plate). 
mean \pm s.e.m. progesterone values for granulosa cells generated from two 18 -mm follicles varied from $3 \cdot 1 \pm 0.4 \mathrm{ng} / \mathrm{ml}$ medium (Follicle $3 \mathrm{~L}_{1}$ ) to $1543 \pm 162 \cdot 1 \mathrm{ng} / \mathrm{ml}$ medium (Follicle $4 \mathrm{R}_{1}$ ). The values for 2 larger follicles were $2324 \pm 481.0 \mathrm{ng} / \mathrm{ml}$ (Follicle $1 \mathrm{~L}_{1}, 25 \mathrm{~mm}$ ) and $455 \pm 143.4 \mathrm{ng} / \mathrm{ml}$ (Follicle $2 \mathrm{~L}_{1}, 23 \mathrm{~mm}$ ).

As seen in Table 3, treatment with 100 i.u. $\mathrm{hCG} / \mathrm{ml}$ did not elicit a significant effect on progesterone secretion by 2 days of culture. However, by 4 days of culture a significant difference $(P<0.05)$ was noted in granulosa cells from all follicles. This significant difference between stimulated and control plates continued throughout the 24 days of culture. Granulosa cell progesterone secretion from 2 representative follicles is depicted in Text-fig. 1. The progesterone response to hCG was coupled with enhancement of SER and increase in annular nexuses at 10 and 24 days of culture. In no case was there evidence of increased steroidogenesis which was not associated with increased SER. Responsiveness to hCG noted after 4 days of culture was not related to the size of the follicles from which granulosa cells had been aspirated. Follicular size did not significantly affect progesterone production by the granulosa cells in vitro under basal or stimulated conditions.

Table 3. The effect of hCG on progesterone secretion from granulosa cells after 2,4 , 10 and 24 days of culture

\begin{tabular}{rcccc}
\hline Day & $\begin{array}{c}\text { Regression } \\
\text { coefficient } \\
(r)\end{array}$ & $\begin{array}{c}\text { Standard } \\
\text { error of } r\end{array}$ & $t$ values & $P$ (2-tail) \\
\hline 2 & -11.9 & 194.8 & -0.06 & 0.9500 \\
4 & 467.4 & 154.4 & 3.02 & 0.0040 \\
10 & 410.5 & 90.0 & 4.55 & 0.0001 \\
24 & 170.4 & 69.1 & 2.46 & 0.0184 \\
\hline
\end{tabular}

Multiple linear regression BMDP IR (1983).

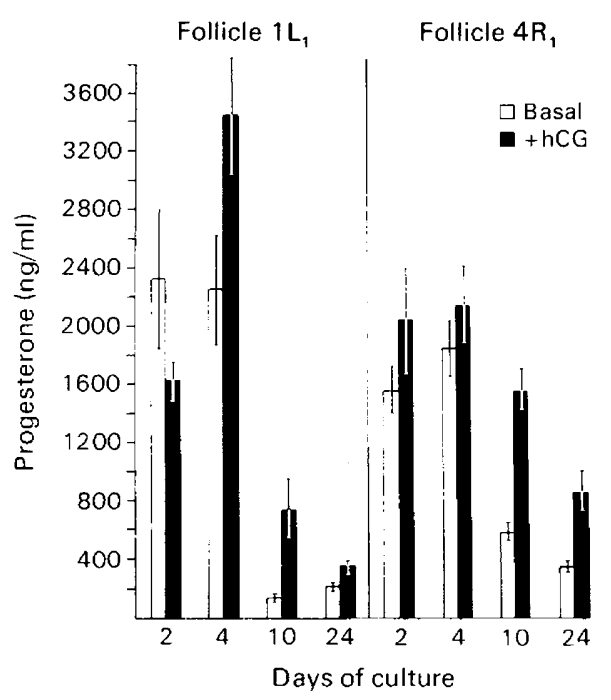

Text-fig. 1. Effect of hCG on progesterone secretion from human granulosa cells aspirated from 2 large preovulatory follicles identified in Table 1. Cells were cultured under basal conditions or incubated with 100 i.u. hCG $/ \mathrm{ml}$. Each bar represents the mean ( \pm s.e.m.) value for culture media from at least 4 culture dishes.

Relaxin was not detected in any sample of culture media, regardless of follicular source, follicular size or exposure to hCG. 


\section{Clinical outcome}

The limited number of follicles prevented statistical comparisons between the clinical outcomes of oocytes and follicular size or granulosa cell culture characteristics at 24 days. However, as depicted in Table 1, oocytes were retrieved from $15-25-\mathrm{mm}$ follicles. All oocytes from 18 to $25-\mathrm{mm}$ follicles and 1 of 2 oocytes from $15-\mathrm{mm}$ follicles cleaved normally and were transferred to the donor uterus. During the treatment cycle in which pregnancy was achieved, all 3 patients had at least one oocyte from an 18-25-mm follicle transferred.

\section{Discussion}

These studies demonstrate that human granulosa cells exposed in vivo to clomiphene citrate and hCG can be maintained as progesterone-secreting cells in a long-term monolayer culture system. Furthermore, granulosa cells from $15-25-\mathrm{mm}$ follicles recovered responsiveness to hCG after 4 days in culture, evident in enhancement of progesterone secretion and ultrastructural modifications of SER and annular nexuses. However, these cells in culture did not develop the specialized lutein function of relaxin secretion, characteristic of the corpus luteum of pregnancy (O'Byrne et al., 1978).

Prolonged exposure in vitro to $\mathrm{hCG}$ was required before enhancement of progesterone production was observed. The biochemical basis for this unique time course remains to be elucidated, but may be related to acclimatization of the cells to culture conditions, to removal from follicular fluid or to steroidogenic blockade before progesterone production. Regardless of the mechanisms involved, our results seem to complement earlier short-term studies of isolated granulosa cells pooled from preovulatory follicles. After a $2-\mathrm{h}$ incubation, $100 \mathrm{i} . \mathrm{u} . \mathrm{hCG} / \mathrm{ml}$ significantly increased tissue levels of cAMP but only "tended to stimulate" progesterone production (Dennefors, Nilsson \& Hamberger, 1982a). When these experiments were repeated using granulosa cells excised from women 24 to $30 \mathrm{~h}$ after i.m. administration of $9000 \mathrm{i} . \mathrm{u}$. hCG, an increase in basal progesterone production in vitro was noted. Once again, however, progesterone enhancement was not significant over the 2-h incubation period (Dennefors, Hamberger \& Nilsson, 1983). The cells from preovulatory follicles exposed to the LH surge in vivo and those from preovulatory follicles exposed to exogenous hCG in vivo responded to 100 i.u. hCG/ml in vitro with increased tissue cAMP formation. Our long-term monolayer cultures of granulosa cells exhibited a clear progesterone response to $100 \mathrm{i} . \mathrm{u}$. hCG $/ \mathrm{ml}$ only after 4 days. Although we first observed a corresponding increase in SER and annular nexuses at 10 days of culture, these ultrastructural changes may have occurred as early as 4 days as suggested by earlier monolayer cultures of pooled granulosa cells (Suzuki et al., 1981).

As elegantly demonstrated by McNatty \& Sawers (1975), the ability of human granulosa cells to secrete progesterone in vitro is predetermined by the follicular microenvironment from which they were removed. Initial exposure to FSH followed by the addition of oestradiol promotes proliferation of the granulosa cells and an increase in LH receptors. It is the "final entry" of LH into the follicle that initiates progesterone secretion. The apparent discrepancy between our present findings and those of Bieszczad et al. (1982) concerning the progesterone responsiveness of cells from small compared to large preovulatory follicles may actually be a function of the length of stimulation in vitro. In the 24-h incubation studies (Bieszczad et al., 1982), only granulosa cells from follicles $<20 \mathrm{~mm}$ responded to ovine $\mathrm{LH}(1 \mu \mathrm{g} / \mathrm{ml})$ with enhanced progesterone production, and the authors suggested that the inability of $\mathrm{LH}$ to affect progesterone secretion by cells from larger follicles might be due to a maximal binding of $\mathrm{LH}$ to the receptors at the time of culture or to desensitization. Our studies of 15-25-mm follicles tend to support the former hypothesis during the first 2 days of culture, but are not consistent with a continued down regulation. In fact, our cultures exhibit prolonged responsiveness to hCG in vitro of all luteinized granulosa cells, consistent with 
the anatomical and functional maintenance of the human corpus luteum observed during pregnancy (Crisp et al., 1973). Throughout the 280-day gestation period, the corpus luteum is thought to secrete both progesterone and relaxin in the presence of hCG (Quagliarello, Szlachter, Steinetz, Goldsmith \& Weiss, 1979), despite failure to detect significant hCG receptors between 6 and 34 weeks of pregnancy (Rao, Griffin \& Carman, 1977). Perhaps, as in ovine luteal cells in monolayer culture (Suter \& Niswender, 1983), LH/hCG receptors may be recycled without increasing in number. As an alternative hypothesis, $\mathrm{LH} / \mathrm{hCG}$ may increase its own receptors in our cultured granulosa cells in a manner similar to the effect of $\mathrm{LH} / \mathrm{hCG}$ upon granulosa cells of preovulatory follicles in the rat (Richards, 1978; Ireland \& Richards, 1978). Quantitation of $\mathrm{LH} / \mathrm{hCG}$ receptors at the time of cell dispersion and at the conclusion of future experiments will clarify this issue. It is also possible that the preovulatory exposure of the granulosa cells in vivo to clomiphene citrate and hCG in our study may have effected responsiveness to hCG in vitro and, hence, may invalidate extrapolation to normal follicles before ovulation.

At the light microscopic level, 2 morphologically distinct populations of cells could be identified. However, because of the relative scarcity of the 'granulosa-type' cells, separation of these two cells must precede ultrastructural comparisons. Since progesterone secretion under basal or stimulated conditions was not affected by the predominance of cell types in culture, the functional difference between the 2 types of cells remains unknown. Our electron microscopic observations are limited to the 'luteal-type' cell. Some of the ultrastructural changes of granulosa cells undergoing luteinization (Adams \& Hertig, 1969; Christensen \& Gillim, 1969) appeared in this in-vitro system, especially under the influence of hCG: the cells possessed non-extractable lipid droplets and developed SER and gap junctions which extended along processes into adjacent cells as annular nexuses. However, even after up to 24 days in culture, the SER never achieved the abundance seen in granulosa lutein cells in situ.

In conclusion, we have shown that human granulosa cells obtained from follicles exposed in vivo to clomiphene citrate and hCG retain the specialized function of progesterone secretion in vitro for up to 24 days. After a time lag of 4 days, these cells recover the ability to respond to hCG with enhanced progesterone secretion, SER and annular nexuses. Therefore, this in-vitro system may be useful in studying, in more detail, the retained endocrine function of progesterone production. Furthermore, this approach may be used to investigate prolonged differentiated functions of other ovarian cells.

We thank Dr B. Steinetz for the R6 antiporcine serum; Dr O. D. Sherwood for the porcine relaxin; the NIAMDD Hormone Distribution Program; Dr Sidney F. Bottoms for statistical expertise; and Ms S. D. Wilbourne for skilled technical assistance. The study was partly supported by a University of Texas Biomedical Research Support Grant (C.L.S.) and a grant from the Rockefeller Foundation (J.Z.K.).

\section{References}

Adams, E.C. \& Hertig, A.T. (1969) Studies on the human corpus luteum. I. Observations on the ultrastructure of development and regression of the luteal cells during the menstrual cycle. J. Cell Biol. 41, 696715.

Batta, S.K., Wentz, A.C. \& Channing, C.P. (1980) Steroidogenesis by human ovarian cell types in culture: influence of mixing of cell types and effect of added testosterone. J. clin. Endocr. Metab. 50, 274279.

Bieszczad, R.R., McClintock, J.S., Pepe, G.J. \& Domino, M.J. (1982) Progesterone secretion by granulosa cells from different sized follicles of human ovaries after short term incubation. J. clin. Endocr. Metab. 55, 181-184.
Blaustein, A. (1977) Anatomy and histology of the human ovary. In The Pathology of the Female Genital Tract, pp. 365-386. Ed. A. Blaustein. Springer-Verlag, New York.

BMDP Statistical Software (1983) University of California Press, Ltd, London, England.

Christensen, A.R. \& Gillim, S.W. (1969) The correlation of fine structure and function in steroid-secreting cells, with emphasis on those of the gonads. In The Gonads, pp. 415-488. Ed. K. McKerns. AppletonCentury-Crofts, New York.

Crisp, T.M., Dessouky, D.A. \& Denys, F.R. (1970) The fine structure of the human corpus luteum of early pregnancy and during the progestational phase of the menstrual cycle. Am. J. Anat. 127, 37-70. 
Crisp, T.M., Dessouky, D.A. \& Denys, F.R. (1973) The fine structure of the human corpus luteum of term pregnancy. Am. J. Obstet. Gynec. 115, 901-911.

Dennefors, B.L., Nilsson, L. \& Hamberger, L. (1982a) Steroid and adenosine 3',5'-monophosphate formation in granulosa and thecal cells from human preovulatory follicles in response to human chorionic gonadotropin. J. clin. Endocr. Metab. 54, 436-441.

Dennefors, B.L., Sjogren, A. \& Hamberger, L. (1982b) Progesterone and adenosine 3',5'-monophosphate formation by isolated human corpora lutea of different ages: influence of human chorionic gonadotropin and prostaglandins. J. clin. Endocr. Metab. 55, 102-107.

Dennefors, B.L., Hamberger, L. \& Nilsson, L. (1983) Influence of human chorionic gonadotropin in vivo on steroid formation and gonadotropin responsiveness of isolated human preovulatory follicular cells. Fert. Steril. 39, 56-61.

Edwards, R.G. \& Steptoe, P.C. (1975) Induction of follicular growth, ovulation and luteinization in the human ovary. J. Reprod. Fert., Suppl. 22, 121-163.

Goldsmith, L.T., Essig, M., Sarosi, P., Beck, P. \& Weiss, G. (1981) Hormone secretion by monolayer cultures of human luteal cells. J. clin. Endocr. Metab. 53, 890. 892.

Ireland, J.J. \& Richards, J.S. (1978) A previously undescribed role for luteinizing hormone ( $\mathrm{HH}: \mathrm{hCG}$ ) on follicular cell differentiation. Endocrinology 102, 1458-1465.

Kendall, J.Z., Richards, G.E., Shih, Li-N. \& Farris, T.E. (1982) Plasma relaxin concentrations in the pig during the periparturient period: association with prolactin, estrogen and progesterone concentrations. Theriogenology 17, 677-687.

Kendall, J.Z., Richards, G.E. \& Shih, Li-N. (1983) Effects of haloperidol, suckling and hand milking on plasma relaxin and prolactin concentrations in cyclic and lactating pigs. J. Reprod. Fert. 69, 271-277.

Malan, P.G. \& Edwards, P.R. (1981) Immunoassay dataprocessing programme; a W.H.O. development project. The Middlesex Hospital Medical School, London.

McNatty, K.P. \& Sawers, R.S. (1975) Relationship between the endocrine environment within the Graafian follicle and the subsequent rate of progesterone secretion by human granulosa cells in vitro. J. Endocr. 66, 391-400.
McNatty, K.P., Makris, A., DeGrazia, C., Osathanondh, R. \& Ryan, K.J. (1979) The production of progesterone, androgens, and estrogens by granulosa cells, thecal tissue, and stromal tissue from human ovaries in vitro. J. clin. Endocr. Metab. 49, 687-699.

O’Byme, E.M., Flitcraft, J.F., Sawyer, W.K., Hochman, J., Weiss, G. \& Steinetz, B.G. (1978) Relaxin bioactivity and immunoactivity in human corpora lutea. Endocrinology 102, 1641-1644.

Quagliarello, J., Szlachter, N., Steinetz, B.G., Goldsmith, L.T. \& Weiss, G. (1979) Serial relaxin concentrations in human pregnancy. Am. J. Obstet. Gynec. 135, 4344.

Quigley, M.M. (1983) The program for in vitro fertilization and embryo transfer at the University of Texas Medical School at Houston. In In Vitro Fertilization and Embryo Transfer. Serono Clinical Colloquia on Reproduction No. 4, pp. 379-391. Eds P. G. Crosignani \& B. L. Rubin. Academic Press, London.

Rao, C.V., Griffin, L.P. \& Carman, F.R. (1977) Gonadotropin receptors in human corpora lutea of the menstrual cycle and pregnancy. Am. J. Obstet. Gynec. 128, 146-153.

Richards, J.S. (1978) Hormonal control of ovarian follicular development: a 1978 perspective. Recent Prog. Horm. Res. 35, 343-373.

Richardson, M.C. \& Masson, G.M. (1980) Progesterone production by dispersed cells from human corpus luteum: stimulation by gonadotrophins and prostaglandin $F_{2}$ : lack of response to adrenaline and isoprenaline. J. Endocr. 87, 247-254.

Suter, D.E. \& Niswender, G.D. (1983) Internalization and degradation of human chorionic gonadotropin in ovine luteal cells: effects of inhibition of protein synthesis. Endocrinology 112, 838-845.

Suzuki, S., Kitai, H., Tojo, R., Seki, K., Oba, M., Fujiwara, T. \& Iizuka, R. (1981) Ultrastructure and some biologic properties of human oocytes and granulosa cells cultured in vitro. Fert. Steril. 35, 142148.

Williams, M.T., Roth, M.S., Marsh, J.M. \& LeMaire, W.J. (1979) Inhibition of human chorionic gonadotropin-induced progesterone synthesis by estradiol in isolated human luteal cells. J. clin. Endocr. Metab. 48, $437-440$.

Received 7 October 1983 